(6) OPEN ACCESS

\title{
Inter-individual variation in midazolam clearance in children
}

\author{
Mohammed I Altamimi, Helen Sammons, Imti Choonara
}

Academic Division of Child Health, University of Nottingham, Derbyshire Children's Hospital, Derby, UK

\section{Correspondence to} Mohammed I Altamimi, Academic Division of Child Health, University of Nottingham, Derbyshire Children's Hospital, Derby DE22 3DT, UK; mzxma2@nottingham.ac.uk

Received 22 November 2013 Revised 9 September 2014 Accepted 10 September 2014 Published Online First 3 October 2014

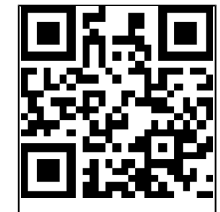

Open Access Scan to access more free content

\section{CrossMark}

To cite: Altamimi MI, Sammons H, Choonara I. Arch Dis Child

2015;100:95-100.

\begin{abstract}
Objectives To determine the extent of inter-individual variation in clearance of midazolam in children and establish which factors are responsible for this variation.

Methods A systematic literature review was performed to identify papers describing the clearance of midazolam in children. The following databases were searched:

Medline, Embase, International Pharmaceutical Abstracts, CINAHL and Cochrane Library. From the papers, the range in plasma clearance and the coefficient of variation (CV) in plasma clearance were determined. Results 25 articles were identified. Only 13 studies gave the full range of clearance values for individual patients. The $\mathrm{CV}$ was greater in critically ill patients $(18 \%-170 \%)$ than non-critically ill patients $(13 \%-$ $54 \%)$. Inter-individual variation was a major problem in all age groups of critically ill patients. The $\mathrm{CV}$ was $72 \%-106 \%$ in preterm neonates, $18 \%-73 \%$ in term neonates, $31 \%-130 \%$ in infants, $21 \%-170 \%$ in children and $47 \%-150 \%$ in adolescents. The mean clearance was higher in children $(1.1-16.7 \mathrm{~mL} / \mathrm{min} / \mathrm{kg})$ than in neonates $(0.78-2.5 \mathrm{~mL} / \mathrm{min} / \mathrm{kg})$.
\end{abstract}

Conclusions Large inter-individual variation was seen in midazolam clearance values in critically ill neonates, infants, children and adolescents.

\section{INTRODUCTION}

Midazolam is a short acting benzodiazepine that is used in the treatment of prolonged seizures and as a sedative for both procedures and critically ill children who are ventilated. ${ }^{1}$ In critically ill children, it is administered by the intravenous route as an infusion. For procedures, it is often administered orally. After oral administration, it is absorbed rapidly from the gastrointestinal tract and the maximum plasma concentration is achieved within $30 \mathrm{~min}$.

Dosing of midazolam, like most medicines used in children, is based on body weight. ${ }^{2-4}$ Dosing in children is usually extrapolated from pharmacokinetic studies in adults. These are initially performed on healthy adult volunteers. Before a medicine is used in children, there is usually significant clinical experience in adults, alongside scientific studies including pharmacokinetic studies in adult patients receiving the medication. These are adults with different illnesses who may handle the drug differently to healthy adult volunteers. Pharmacokinetic studies in children receiving midazolam are of benefit in ensuring that appropriate doses are given. However, doses are usually calculated from mean pharmacokinetic values. It is important to be aware that there is often significant inter-individual variation in the pharmacokinetics, and in particular the clearance of a medicine, due to factors such as

\section{What is already known on this topic}

Midazolam clearance varies with age.

- Critical illness is a major determinant of clearance.

\section{What this study adds}

- There is a large inter-individual variation in midazolam clearance in critically ill children and neonates.

- It is likely that many critically ill children are either underdosed or overdosed with midazolam.

age, ${ }^{5}$ weight, ${ }^{6}$ disease $^{7}$ and ethnicity/genotype. ${ }^{8}$ Recently, other more specific methods such as population pharmacokinetics (PK) modelling have been developed. This allows for age appropriate individualisation of dosing for children. ${ }^{9}$

We wished to explore which factors were associated with the greatest inter-individual variation in midazolam clearance in paediatric patients. We therefore performed a systematic review of pharmacokinetic studies in paediatric patients involving midazolam.

\section{METHODS}

A systematic literature search was performed to identify all papers describing the clearance of midazolam in children. The following databases were used: MEDLINE (1946 to May 2012), EMBASE (1974 to May 2012), International Pharmaceutical Abstracts (1970 to April 2012), CINAHL and Cochrane Library. The databases were searched separately and combined together to remove duplications. The search strategy included all languages and involved the keywords: 'midazolam' AND 'child"' OR 'p*ediatric"' OR 'infant"' OR 'new-born"' OR 'neonate", OR 'adolescent"' AND 'pharmacokinetic"' OR 'clearance' OR 'half-life' OR 'absorption' OR ‘distribution' OR 'metabolism' OR 'elimination' OR 'pharmacodynamic" ${ }^{*}{ }^{10}$

We excluded the following: review articles, editorials, conference abstracts, studies in adults aged 18 years and over, and studies that involved adults and paediatric patients where the paediatric data were not presented separately. Studies in which midazolam was not administered intravenously were also excluded as clearance is dependent on 
bioavailability if administered orally or rectally. Inclusion criteria were original research studies assessing the pharmacokinetics of midazolam in children up to the age of 18 years. Data such as number of patients, ethnicity, dose and clearance were extracted. The mean/median clearance as well as both the minimum and maximum clearance values was noted. The variation ratio was calculated from the range of clearance (maximum clearance divided by the minimum clearance). The coefficient of variation (CV) was extracted from the paper if given. If individual data were presented, then the $\mathrm{CV}$ was calculated using the formula $\mathrm{CV}=\sqrt{\left(\left(\mathrm{e}^{\mathrm{SD}^{2}}\right)-1\right)}$ which allows for the fact that clearance is usually $\log$ normally distributed in children. If individual data were not available, then CV was estimated by dividing the SD by the mean of clearance, i.e., normal distribution assumed. Patients were divided into two groups: (1) critically ill if they were in an intensive care unit and (2) non-critically ill which included other groups. We also contacted original authors by email if their paper did not give the full range of clearance values but only gave mean clearance values.
RESULTS

A total of 1654 articles were identified but only 25 articles met the inclusion criteria ${ }^{71-34}$ (figure 1). The 1367 articles that were excluded were 613 studies where data for midazolam were not presented, 359 studies that did not give data for midazolam pharmacokinetics, 245 review articles, 122 studies in adults, 16 conference abstracts, eight editorials, and one study involving adults and paediatric patients where the paediatric data were not presented separately. Three studies that involved oral/rectal administration of midazolam were excluded. Two authors provided individual data in response to the email request and this has been included in the table. Fourteen studies stated the compartment model used for the PK analysis. Seven used a two compartment model, ${ }^{11} 12 \quad 1415171821$ one used a three compartment model, ${ }^{31}$ one used both one and two compartment model $^{17}$ and five used a non-compartment model. ${ }^{13} \quad \begin{array}{llll}16 & 24 & 25 & 28\end{array}$ Ethnicity was described in only four studies. ${ }^{15} \quad \begin{array}{lllll}16 & 24 & 30 & \text { All }\end{array}$ studies except two were population PK studies. Six papers stated the CV. ${ }^{14} 1^{15}{ }^{17-19} 21$ Six other papers provided individual data allowing calculation of CV. ${ }^{12} 1620222931$ In nine papers, only

Figure 1 Flow chart of the search performed.

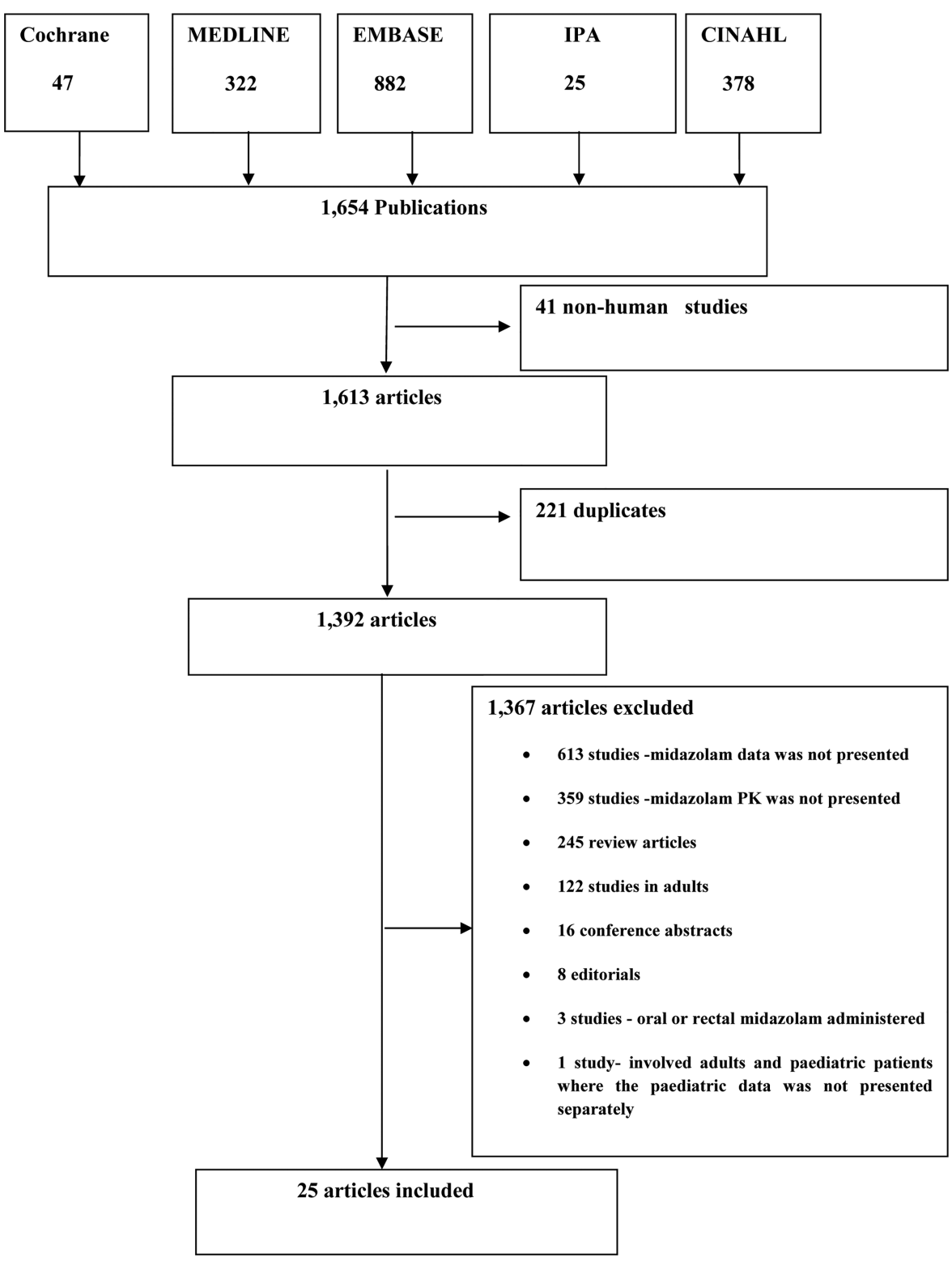




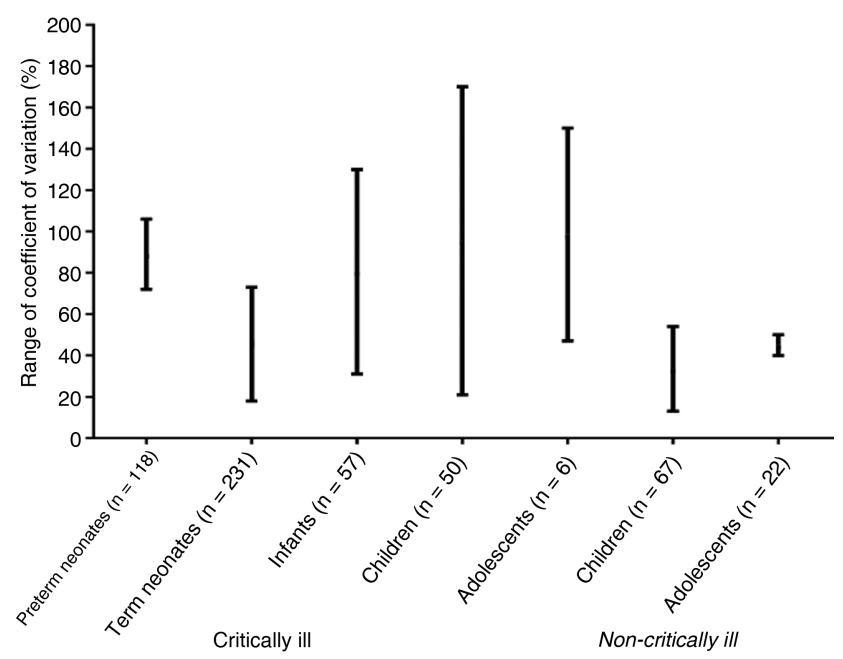

Figure 2 Range of coefficient of variation for different patient groups.

the SD was reported and therefore CV was estimated assuming normal distribution. ${ }^{11} 2025-28303334$ The CV for all paediatric age groups ranged between $13 \%$ and $170 \%$ (figure 2).

Nine studies reported midazolam clearance in 349 critically ill neonates undergoing sedation for mechanical ventilation (table 1). The $\mathrm{CV}$ in four studies in preterm neonates ranged from $72 \%$ to $106 \%$. The CV in four studies in term neonates ranged from $18 \%$ to $73 \%$. Four studies gave the full range of clearance values for individual neonates. ${ }^{11-13} 16$ Three studies in preterm neonates suggested a 4.5-, 5- and 10-fold variation in clearance in 15,10 and 24 neonates, respectively. ${ }^{11-13}$ One study involving five term neonates reported a twofold variation in clearance. ${ }^{16}$ The mean clearance in preterm neonates ranged from 0.78 to $2.1 \mathrm{~mL} / \mathrm{kg} / \mathrm{min}$ and in term neonates ranged from 1.17 to $2.5 \mathrm{~mL} / \mathrm{kg} / \mathrm{min}$.

Four studies reported midazolam clearance in critically ill infants. $^{16}{ }^{20-22}$ The CV ranged from $31 \%$ to $130 \%$. The CV was lowest in the study where the infants were not ventilated. ${ }^{21}$ All four studies gave the full range of clearance values for individual infants. There was a $6-43$-fold variation in clearance values.

Five studies reported clearance values in critically ill children. ${ }^{16} 2023-25$ The CV ranged from $21 \%$ to $170 \%$. Four studies gave the full range of clearance values for individual children. There was a twofold to fivefold variation in clearance values in three studies and a 133 -fold variation in one study. ${ }^{16202324}$

Two small studies in critically ill adolescents had a CV of $47 \%$ and $150 \%$. There was a $2.5-5$-fold variation in clearance values.

Three other studies in critically ill children included data from neonates and did not present the data in relation to age (table 1). The CV was $78 \%$ in both of these studies. There was a 29-32-fold variation in clearance values.

The studies in critically ill neonates, infants, children and adolescents all documented significant inter-individual variation in clearance. One study where the authors provided individual data excluded data from three patients where there was even greater inter-individual variation due to their renal failure, hepatic failure and concomitant erythromycin-fentanyl therapy. ${ }^{16}$

There were seven studies that reported midazolam clearance in non-critically ill infants, children and adolescents (table 2). The CV ranged from $13 \%$ to $54 \%$. Four of these studies gave the full range of clearance values for individual patients. ${ }^{29-32}$ The degree of inter-individual variation in clearance in these children ranged from 2-fold up to 10.5 -fold.

The mean clearance was highest in children and lowest in preterm neonates. The CV was greater in critically ill patients of all ages than non-critically ill (table 3 ).

\section{DISCUSSION}

Inter-individual variation in midazolam clearance was greater in critically ill patients than non-critically ill patients. The CV was greater than $50 \%$ in the majority of studies in critically ill patients. Midazolam is administered by a continuous intravenous infusion in critically ill children and the dose is titrated in relation to the response. There is a fourfold variation in dosage administration $(30-120 \mu \mathrm{g} / \mathrm{kg} / \mathrm{h})$ for children between the ages of 6 months and 12 years. ${ }^{3}$ There was, however, a greater than fourfold variation in midazolam clearance in the majority of studies in the critically ill. The greater variation in midazolam clearance values than the dosage schedule suggests that many children may receive too high or too low a dose of midazolam in order to obtain satisfactory sedation. This may explain the poor sedation achieved in clinical trials with midazolam in critically ill children. ${ }^{35}$

Critical illness may extensively affect midazolam clearance in both children ${ }^{36}$ and adults. ${ }^{37} 38$ Three studies in critically ill adults suggested a 12-20-fold variation in midazolam clearance with variation in dose between 2 - and 10 -fold. ${ }^{37-39}$ One of the first studies of midazolam in critically ill children described a 40 -fold variation in plasma concentrations of midazolam despite there being only a 2.5 -fold variation in dosage. ${ }^{40}$ Several factors can affect the pharmacokinetics of drugs in critically ill patients. ${ }^{41}$ Both hypoxia and shock are common in the critically ill. The liver is sensitive to hypoxia as the majority of its blood supply is from the portal vein where blood has a low oxygen content. ${ }^{41}$ Hypoxia can affect the cells in the liver which are responsible for blood metabolism. Shock which is common in critically ill patients, especially prior to admission to an intensive care unit, results in a reduced blood flow to the liver, which results in a reduction in enzyme activity in hepatocytes. The clearance of morphine was reduced in adults with shock following acute trauma. ${ }^{42}$ Other factors that can affect drug metabolism in the critically ill include systemic inflammatory responses. $^{41}$ Inflammatory mediators such as interleukin 1, interleukin 6, tumour necrosis factors and interferon may all have an effect on drug metabolism. ${ }^{43}$ Stress, changes in diet, endocrine changes and other drugs may also affect drug metabolism. ${ }^{41}$ Mechanical ventilation can reduce cardiac output and therefore reduce blood flow to the organs, especially the liver and kidneys, which are responsible for drug clearance. ${ }^{44}$ However, reduced blood flow to the liver does not substantially affect midazolam clearance as it is not a high extraction ratio drug. Changes in volume of distribution can occur as a result of infection and inflammation in critically ill patients. Endotoxins from infective agents can affect the endothelium of blood vessels, causing either vasoconstriction or vasodilatation which can lead to abnormal distribution of drugs. ${ }^{41}$

There was significant inter-individual variation in critically ill neonates with a $2-10$-fold variation in plasma clearance values and CV between $18 \%$ and $106 \%$. Midazolam is administered by continuous intravenous infusion in critically ill neonates and the dose titrated according to the response. However, there is no 10 -fold variation in doses used in neonates. In the papers listed in this review, there was a fourfold variation in midazolam dosage in neonates. The CV was greater in preterm neonates 


\begin{tabular}{|c|c|c|c|c|c|c|c|c|c|}
\hline Age group & Number of patients & $\begin{array}{l}\text { Range of } \\
\text { weight }(\mathrm{kg})\end{array}$ & $\begin{array}{l}\text { Mean clearance } \\
(\mathrm{mL} / \mathrm{kg} / \mathrm{min})\end{array}$ & SD & $\begin{array}{l}\text { Coefficient of } \\
\text { variation (CV) (\%) }\end{array}$ & $\begin{array}{l}\text { Range of clearance } \\
(\mathrm{mL} / \mathrm{kg} / \mathrm{min})\end{array}$ & $\begin{array}{l}\text { Variation ratio } \\
\text { in clearance }\end{array}$ & Comments & Study \\
\hline Preterm neonates & $\begin{array}{r}15 \\
10 \\
24 \\
9 \\
33 \\
27\end{array}$ & $\begin{array}{l}1-3.3 \\
2.3-3.9 \\
0.8-1.6 \\
0.7-1.4 \\
0.5-1 \\
1-1.65\end{array}$ & $\begin{array}{l}1.7 \\
2.1 \\
1.8^{*} \\
1.7 \\
0.78 \\
1.24\end{array}$ & $\begin{array}{c}1.8 \\
1.3 \\
\text { NA } \\
1.4 \\
0.6 \\
0.9\end{array}$ & $\begin{array}{r}106 \\
72 \\
\text { NA } \\
81 \\
83 \\
78\end{array}$ & $\begin{array}{l}0.6-2.7 \\
0.7-3.7 \\
0.7-6.7 \\
\text { NA } \\
\text { NA } \\
\text { NA }\end{array}$ & $\begin{array}{l}4.5 \\
5 \\
10 \\
\text { NA } \\
\text { NA } \\
\text { NA }\end{array}$ & $\begin{array}{l}\text { Individual data available } \\
- \\
\text { CV provided by authors } \\
\text { The only population PK study with } \\
\text { omega } 2 \text { leta values } \\
\text { CV provided by authors }\end{array}$ & $\begin{array}{l}\text { Jacqz-Aigrain et al } 1^{11} \\
\text { Jacqz-Aigrain et al } \\
\text { de Wildt et al }{ }^{12} \\
\text { Harte et al } 1^{14} \\
\text { Lee et } a l^{15}\end{array}$ \\
\hline \multirow[t]{4}{*}{ Term neonates } & 5 & $2.8-3.8$ & 2.5 & 0.75 & 30 & $1.8-3.7$ & 2 & $\begin{array}{l}\text { Two stage PK study } \\
\text { Individual data available }\end{array}$ & de Wildt et $a l^{16}$ \\
\hline & 187 & $0.7-5.2$ & $\begin{array}{l}1.17<39 / 40 \mathrm{GA} \\
1.84>39 / 40 \mathrm{GA}\end{array}$ & $\begin{array}{l}0.7 \\
1.2\end{array}$ & 65 & NA & NA & CV provided by authors & Burtin et $a l^{17}$ \\
\hline & 20 & $2.7-3.9$ & 2.6 & NA & 18 & NA & NA & $\begin{array}{l}\text { Pre-ECMO } \\
\text { CV provided by authors }\end{array}$ & Ahsman et al ${ }^{18}$ \\
\hline & 19 & $3.4 \dagger$ & 1.4 & 1 & 73 & NA & NA & $\begin{array}{l}\text { Post-ECMO } \\
\text { CV provided by authors }\end{array}$ & Mulla et $a l^{19}$ \\
\hline \multirow[t]{3}{*}{$>28$ days -23 months } & $\begin{array}{r}25 \\
6\end{array}$ & $\begin{array}{l}\text { NA } \\
3.6-20\end{array}$ & $\begin{array}{l}6 \\
4.8\end{array}$ & $\begin{array}{l}7 \\
5\end{array}$ & $\begin{array}{r}130 \\
89\end{array}$ & $\begin{array}{l}0.6-25.8 \\
1.8-16\end{array}$ & $\begin{array}{l}43 \\
9\end{array}$ & $\begin{array}{l}\text { Individual data available } \\
\text { Two stage PK study } \\
\text { Individual data available }\end{array}$ & $\begin{array}{l}\text { Hughes et } a l^{20} \\
\text { de Wildt et } a l^{16}\end{array}$ \\
\hline & 24 & $5.1-12$ & 16.7 & 5.2 & 31 & $0.1-0.6$ & 6 & $\begin{array}{l}\text { Not ventilated, } \mathrm{mL} / \mathrm{min}\left(\text { not } \mathrm{kg}^{-1} \text { ) }\right. \\
\mathrm{CV} \text { provided by authors }\end{array}$ & Peeters et al ${ }^{21}$ \\
\hline & 2 & NA & 2 & 1.8 & 50 & $0.4-3$ & 7.5 & $\begin{array}{l}\text { Two stage PK study } \\
\text { Individual data available }\end{array}$ & Minagawa and Watanabe ${ }^{22}$ \\
\hline \multirow[t]{6}{*}{$2-11$ years } & $\begin{array}{l}5 \\
4\end{array}$ & $\begin{array}{l}13-88 \\
15-40\end{array}$ & $\begin{array}{l}1.1 \\
6\end{array}$ & $\begin{array}{c}\text { NA } \\
3.8\end{array}$ & $\begin{array}{l}\text { NA } \\
72\end{array}$ & $\begin{array}{l}0.9-3.8 \\
2.3-11\end{array}$ & $\begin{array}{l}4 \\
5\end{array}$ & $\begin{array}{l}\text { Two stage PK study } \\
\text { Individual data available }\end{array}$ & $\begin{array}{l}\text { Roberts et } a l^{23} \\
\text { de Wildt et } a l^{16}\end{array}$ \\
\hline & 12 & $8.7-12$ & 14.4 & NA & NA & $9.2-19.7$ & 2 & - & Muchohi et $a l^{24}$ \\
\hline & 12 & NA & 15.5 & 20 & 170 & $0.5-66.6$ & 133 & Individual data available & Hughes et $a l^{20}$ \\
\hline & 6 & $6.4-25$ & 12 & 6.6 & 55 & NA & NA & - & Mathews et $a l^{25}$ \\
\hline & 6 & & 8.5 & 1.8 & 21 & NA & NA & - & \\
\hline & 5 & & 9.1 & 3.4 & 37 & NA & NA & - & \\
\hline $12-18$ years & $\begin{array}{l}3 \\
3\end{array}$ & $\begin{array}{l}50-62 \\
\text { NA }\end{array}$ & $\begin{array}{l}3.2 \\
5\end{array}$ & $\begin{array}{l}1.6 \\
4.5\end{array}$ & $\begin{array}{r}47 \\
150\end{array}$ & $\begin{array}{l}2-5 \\
1.5-8\end{array}$ & $\begin{array}{l}2.5 \\
5\end{array}$ & $\begin{array}{l}\text { - } \\
\text { Two stage PK study } \\
\text { Individual data available }\end{array}$ & $\begin{array}{l}\text { de Wildt et } a l^{16} \\
\text { Minagawa }\end{array}$ \\
\hline 2 days -17 years & 21 & $3.8-24.5$ & 5 & 3.9 & 78 & NA & NA & - & Vet et $a l^{26}$ \\
\hline 8 days -16.2 years & 22 & NA & NA & NA & NA & $1.6-51.6$ & 32 & - & Nahara et al $l^{7}$ \\
\hline 26 days -5 years & 24 & NA & 13.5 & 10.6 & 78 & $1.5-43.4$ & 29 & - & Hartwig et $a l^{27}$ \\
\hline
\end{tabular}


Table 2 Midazolam clearance in non-critically ill children

\begin{tabular}{|c|c|c|c|c|c|c|c|c|c|c|}
\hline Age group & $\begin{array}{l}\text { Number of } \\
\text { patients }\end{array}$ & $\begin{array}{l}\text { Range of } \\
\text { weight (kg) }\end{array}$ & $\begin{array}{l}\text { Mean } \\
\text { clearance } \\
\text { (mL/kg/min) }\end{array}$ & SD & $\begin{array}{l}\text { Coefficient of } \\
\text { variation (\%) }\end{array}$ & $\begin{array}{l}\text { Range of } \\
\text { clearance } \\
\text { (mL/kg/min) }\end{array}$ & $\begin{array}{l}\text { Variation ratio } \\
\text { in clearance }\end{array}$ & $\begin{array}{l}\text { Type of } \\
\text { patients }\end{array}$ & Comments & Study \\
\hline $\begin{array}{l}>28 \text { days- } \\
23 \text { months }\end{array}$ & 5 & $2.8-12.8$ & 11.3 & 6 & 53 & NA & NA & Minor surgery & $\begin{array}{l}\text { Two stage PK } \\
\text { study }\end{array}$ & Reed et $a l^{28}$ \\
\hline \multirow[t]{6}{*}{ 2-11 years } & 6 & $11-17$ & 13.3 & 4 & 41 & $9.5-17.8$ & 2 & Minor surgery & $\begin{array}{l}\text { Individual data } \\
\text { available }\end{array}$ & Rey et $a l^{29}$ \\
\hline & 12 & $14-38.5$ & 15.3 & 3.1 & 20 & $11-23$ & 2 & Minor surgery & - & Jones et $a l^{30}$ \\
\hline & 6 & $22-30$ & 3.2 & 1.1 & 54 & $1.1-6.5$ & 6 & Minor surgery & $\begin{array}{l}\text { Individual data } \\
\text { available }\end{array}$ & Kraus et $a l^{31}$ \\
\hline & 21 & $23.2^{*}$ & NA & NA & NA & $1.3-13.7$ & 10.5 & Elective surgery & - & Salonen et $a l^{32}$ \\
\hline & 14 & $19.5^{*}$ & 10 & 3.8 & 38 & NA & NA & Minor surgery & $\begin{array}{l}\text { Two stage PK } \\
\text { study }\end{array}$ & Reed et $a l^{28}$ \\
\hline & 8 & $8.4-26.2$ & 9.1 & 1.2 & 13 & NA & NA & Minor surgery & - & Payne et $a l^{\beta 3}$ \\
\hline \multirow[t]{2}{*}{$12-18$ years } & 20 & NA & 10 & 5 & 50 & NA & NA & Endoscopy & - & Tolia et $a l^{34}$ \\
\hline & 2 & $62 *$ & 9.3 & 3.8 & 40 & NA & NA & Minor surgery & $\begin{array}{l}\text { Two stage PK } \\
\text { study }\end{array}$ & Reed et $a l^{28}$ \\
\hline
\end{tabular}

*Mean.

NA, not available.

$(72 \%-106 \%)$ than term neonates $(18 \%-73 \%)$. Clearance is lower in neonates than older children and adolescents due to the immaturity of drug metabolism process in neonates.

The major pathway of midazolam metabolism is oxidation, which involves the cytochrome P450 (CYP) dependent enzymes. The major CYP enzymes are CYP3A4, CYP3A5 and CYP3A7. CYP3A4 activity is significantly reduced in neonates. CYP3A7 has the greatest activity in the neonatal period, but does not contribute substantially to metabolism. ${ }^{45}$ There is, however, less inter-individual variation in CYP3A7 mRNA in fetal liver than variations in CYP3A4 levels found in adult liver. ${ }^{46}$ CYP3A4 levels increase progressively from about a tenth of adult levels in preterm neonates to approximately adult levels at 6 months.

Inter-individual variation in midazolam clearance was lower in non-critically ill children. The $\mathrm{CV}$ was however still large $(13 \%-54 \%)$ with a $2-10$-fold variation in plasma clearance values. This suggests that even non-critically ill children may be overdosed or underdosed. A recent study developed a modelbased approach to individualise midazolam dose based on in vivo maturation function for CYP3A mediated clearance from birth to adulthood. ${ }^{47}$ Model-based approaches are a welcome addition to ensuring paediatric patients receive the correct dose. However, models do not eliminate inter-individual variation. One therefore needs to titrate the dose.

The role of genetic polymorphism of CYP3A in interindividual variation of drug disposition has been studied previously. This review could not distinguish any differences in variability between different ethnic subpopulations as the majority of the studies did not document the ethnicity of the sample patients.

Table 3 Coefficient of variation for midazolam clearance in paediatrics

\begin{tabular}{lll}
\hline Age & Critically ill (\%) (n) & Non-critically ill (\%) (n) \\
\hline Preterm neonates & $72-106(118)$ & - \\
Term neonates & $18-73(231)$ & - \\
Infants & $31-130(57)$ & $53(5)$ \\
children & $21-170(50)$ & $13-54(67)$ \\
Adolescents & $47-150(6)$ & $40-50(22)$ \\
\hline
\end{tabular}

In conclusion, this systematic review has identified that interindividual variation in midazolam clearance is greatest in critically ill children and neonates. The degree of inter-individual variation in critically ill paediatric patients is far greater than the variation in doses administered. This suggests that some patients may receive inadequate doses while others receive excessive doses. Assessment of the response to midazolam in these clinical situations is therefore essential with recognition that higher doses may be needed to achieve adequate sedation. More research is also needed to establish the safety of higher dose ranges.

Acknowledgements We would like to thank Dr Saskia De Wildt and Professor John van den Anker for providing individual data for their patients.

Contributors MIA, HS and IC conceived the idea as part of MIA's PhD. MIA did the literature search and extracted the data. HS and IC reviewed and validated the extracted data. MIA wrote the first draft and IC edited the draft and subsequent drafts. MIA, HS and IC agreed to the final draft.

\section{Funding None.}

\section{Competing interests None.}

Provenance and peer review Not commissioned; externally peer reviewed.

Open Access This is an Open Access article distributed in accordance with the Creative Commons Attribution Non Commercial (CC BY-NC 3.0) license, which permits others to distribute, remix, adapt, build upon this work non-commercially, and license their derivative works on different terms, provided the original work is properly cited and the use is non-commercial. See: http://creativecommons.org/ licenses/by-nc/3.0/

\section{REFERENCES}

1 Blumer JL. Clinical pharmacology of midazolam in infants and children. Clin Pharmacokinet 1998;35:37-47.

2 Baber N, Pritchard D. Dose estimation for children. Br J ClinPharmacol 2003;46:489-93.

3 Paediatric Formulary Committee. BNF for children. London: BMJ Group, Pharmaceutical Press, and RCPCH Publications, 2013-2014:638-39.

4 Anderson $\mathrm{BJ}$, Holford $\mathrm{NH}$. Understanding dosing: children are small adults, neonates are immature children. Arch Dis Child 2013;98:737-44.

5 De Gast-Bakker DA, van der Werff SD, Sibarani-Ponsen R, et al. Age is of influence on midazolam requirements in a paediatric intensive care unit. Acta Paediatr 2007;96:414-17

6 Maitre PO, Buhrer M, Thomson D, et al. A three-step approach combining Bayesian regression and NONMEM population analysis: application to midazolam. J Pharmacokinet Biopharm 1991;19:377-84.

7 Nahara M, McMorrow J, Jones $P$, et al. Pharmacokinetics of midazolam in critically ill paediatric patients. Eur J Drug Metab Pharmacokinet 2000;25:219-21. 
8 Guo T, Mao GF, Xia DY, et al. Pharmacokinetics of midazolam tablet in different Chinese ethnic groups. J Clin Pharm Ther 2011;36:406-11.

9 Admiraal R, van Kesteren C, Boelens JJ, et al. Towards evidence-based dosing regimens in children on the basis of population pharmacokinetic pharmacodynamic modelling. Arc Dis Child 2014;99:267-72.

10 Kastner M, Wilczynski NL, Walker-Dilks C, et al. Age-specific search strategies for Medline. J Med Internet Res 2006;8:25.

11 Jacqz-Aigrain E, Daoud P, Burtin P, et al. Pharmacokinetics of midazolam during continuous infusion in critically ill neonates. Eur J Clin Pharmacol 1992;42:329-32.

12 Jacqz-Aigrain E, Wood C, Robieux I. Pharmacokinetics of midazolam in critically ill neonates. Eur J Clin Pharmacol 1990;39:191-2.

13 De Wildt SN, Kearns GL, Hop WC, et al. Pharmacokinetics and metabolism of intravenous midazolam in preterm infants. Clin Pharmacol Ther 2001;70:525-31.

14 Harte GJ, Gray PH, Lee TC, et al. Haemodynamic responses and population pharmacokinetics of midazolam following administration to ventilated, preterm neonates. J Paediatr Child Health 1997;33:335-8.

15 Lee TC, Charles BG, Harte GJ, et al. Population pharmacokinetic modeling in very premature infants receiving midazolam during mechanical ventilation: midazolam neonatal pharmacokinetics. Anesthesiology 1999;90:451-7.

16 De Wildt SN, de Hoog M, Vinks AA, et al. Population pharmacokinetics and metabolism of midazolam in pediatric intensive care patients. Crit Care Med 2003;31:1952-8.

17 Burtin $\mathrm{P}$, Jacqz-Aigrain E, Girard $\mathrm{P}$, et al. Population pharmacokinetics of midazolam in neonates. Clin Pharmacol Ther 1994;56:615-25.

18 Ahsman MJ, Hanekamp M, Wildschut ED, et al. Population pharmacokinetics of midazolam and its metabolites during venoarterial extracorporeal membrane oxygenation in neonates. Clin Pharmacokinet 2010;49:407-19.

19 Mulla $\mathrm{H}, \mathrm{McC}$ ormack $\mathrm{P}$, Lawson $\mathrm{G}$, et al. Pharmacokinetics of midazolam in neonates undergoing extracorporeal membrane oxygenation. Anesthesiology 2003;99:275-82.

20 Hughes J, Gill AM, Choonara I, et al. Steady-state plasma concentrations of midazolam in critically ill infants and children. Ann Pharmacother 1996;30:27-30.

21 Peeters MY, Prins SA, Knibbe CA, et al. Pharmacokinetics and pharmacodynamics of midazolam and metabolites in nonventilated infants after craniofacial surgery. Anesthesiology 2006;105:1135-46.

22 Minagawa K, Watanabe T. [A pharmacokinetic study of midazolam for the treatment of status epilepticus in children: a preliminary report]. No To Hattatsu 2006:38:301-3.

23 Roberts JA, Coulthard MG, Addison RS, et al. Midazolam metabolism: implications for individualized dosing? J Pharm Pract Res 2009;39:198-201.

24 Muchohi SN, Kokwaro GO, Ogutu BR, et al. Pharmacokinetics and clinical efficacy of midazolam in children with severe malaria and convulsions. Br J Clin Pharmacol 2008;66:529-38.

25 Mathews HM, Carson IW, Lyons SM, et al. A pharmacokinetic study of midazolam in paediatric patients undergoing cardiac surgery. Br J Anaesth 1988;61:302-7.

26 Vet NJ, de Hoog M, Tibboel D, et al. The effect of critical illness and inflammation on midazolam therapy in children. Pediatr Crit Care Med 2012;13:48-50.

27 Hartwig S, Roth B, Theisohn M. Clinical experience with continuous intravenous sedation using midazolam and fentanyl in the paediatric intensive care unit. Eur Journal Pediatr 1991;150:784-8.
28 Reed MD, Rodarte A, Blumer JL, et al. The single-dose pharmacokinetics of midazolam and its primary metabolite in pediatric patients after oral and intravenous administration. J Clin Pharmacol 2001;4:1359-69.

29 Rey E, Delaunay L, Pons G, et al. Pharmacokinetics of midazolam in children: comparative study of intranasal and intravenous administration. Eur J Clin Pharmacol 1991;41:355-7.

30 Jones RD, Chan K, Roulson CJ, et al. Pharmacokinetics of flumazenil and midazolam. Br J Anaesth 1993;70:286-92.

31 Kraus GB, Gruber RG, Knoll R, et al. [Pharmacokinetic studies following intravenous and rectal administration of midazolam in children]. Anaesthesist 1989;38:658-63.

32 Salonen $\mathrm{M}$, Kanto J, lisalo $\mathrm{E}$, et al. Midazolam as an induction agent in children: a pharmacokinetic and clinical study. Anesth Analg 1987;66:625-8.

33 Payne K, Mattheyse FJ, Liebenberg D, et al. The pharmacokinetics of midazolam in paediatric patients. Eur J Clin Pharmacol 1989;37:267-72.

34 Tolia V, Brennan S, Aravind MK, et al. Pharmacokinetic and pharmacodynamic study of midazolam in children during esophagogastroduodenoscopy. J Pediatr 1991;119:467-71.

35 Parkinson I, Hughes J, Choonara I, et al. A randomized controlled trial of sedation in the critically ill. JAMA 1997;7:405-510.

36 Ince I, de Wildt SN, Peeters MYM, et al. Critical illness is a major determinant of midazolam clearance in children aged 1 month to 17 years. Ther Drug Monit 2012;34:381-9.

37 Shafer A, van Doze A, White PF, et al. Pharmacokinetic variability of midazolam infusions in critically ill patients. Crit Care Med 1990;18:1039-41.

38 Kinoshita K, Sakurai A, Mera K, et al. Midazolam for continuous sedation in Japanese critical care patients: Phase II study. J Int Med Res 2001;29: 342-8.

39 Oldenhof $\mathrm{H}$, de Jong M, Steenhoek A, et al. Clinical Pharmacokinetics of midazolam in intensive care patients, a wide interpatient variability? Clin Pharmacol Ther 1988;43:263-9.

40 Lloyd-Thomas AR, Booker PD. Infusion of midazolam in paediatric patients after cardiac surgery. Br J Anaesth 1986;58:1109-15.

41 Park GR. Molecular mechanisms of drug metabolism in the critically ill. Br J Anaesth 1996;77:32-49.

42 Christie J, Markowsky SJ, Valdes C. Acute trauma alters morphine clearance. J Trauma 1995:39:749-52.

43 Morgan ET. Impact of infectious and inflammatory disease on cytochrome P450-mediated drug metabolism and pharmacokinetics. Clin Pharmacol Ther 2009;85:434-8.

44 Richard C, Berdeaux A, Delion F, et al. Effect of mechanical ventilation on hepatic drug pharmacokinetics. Chest 1966;90:837-41.

45 Williams JA, Ring BJ, Cantrell VE, et al. Comparative metabolic capabilities of CYP3A4, CYP3A5, and CYP3A7. Drug Metab Dispos 2002;30:883-91.

46 DeWildt SN, Kearns GL, Leeder JS, et al. Cytochrome P450 3A: ontogeny and drug disposition. Clin Pharmacokinet 1999;37:485-505.

47 Ince I, de Wildt SN, Wang C, et al. A novel maturation function for clearance of the cytochrome P450 3A substrate midazolam from preterm neonates to adults. Clin Pharmacokinet 2013;52:555-65. 